\title{
CONTENT ANALYSIS OF SOCIAL CRITICAL IN ANTITANK-PROJECT INSTAGRAM ACCOUNT
}

\author{
Wipti Aga Pramasepta, Christina Rochayanti, Kartika Ayu Ardhanariswari \\ Department of Communication Science \\ Faculty of Social and Political Sciences, UPN "Veteran" Yogyakarta
}

\author{
Email: wptgalz@gmail.com
}

\begin{abstract}
Criticism is one element that can keep the existing system in its tracks and not get out of the way the system should be. Anti-tank has initially been one of the artists and activists who expressed their criticism using posters in Yogyakarta. This study aims to determine the content of criticism in the Antitank Project and the tendency of criticism. The method is content analysis. The theory used is the spiral silence theory and Habermas' critical theory. The study population amounted to 192 images in the period of January 2016 - December 2018. The study sample was taken 46 pictures to be examined because of the repetition of several photographs. The research results show that there is a tendency in Antitank criticism, namely in the political field, in which there is an important element of power and has high publicity. The object of criticism of Anti-tank's dominant work is the state government, which holds the country's highest authority. Communication of indirect criticism works or symbols becomes dominant in Antitank social criticism works. The use of symbols is more interesting and wise, to reduce conflict with the object of criticism. Antitank uploads through Instagram to get broad support and increase the approach to his work to cause movement to a broad audience by the theory adopted, namely the spiral of silence theory.
\end{abstract}

Keywords: Works, Social criticism, Instagram, Anti-tank

\section{INTRODUCTION}

Criticism is a familiar word in the current era. Criticism is usually synonymous with comments that are looking for mistakes and short gaps in the response. From the criticism response, it can provoke other pro or contra responses with the criticism, many assumptions that will arise with criticism. Because criticism is also a subjective assumption from someone, it can be based on data and research or only words released freely without any foundation. But with the support of data or facts on the ground can be one of the tools to help the country improve a system that is indeed off track from the system that should be.

In conveying their messages, critics can use general mass media or use new media or directly, such as holding demonstrations or demonstrations. One part of the criticism is a protest; protests can be based on any field, for example, social, gender education, a political religion, and many more. In the web created by two men named Tommy Leung and Nathan Perkins, 
gives an overview of maps and statistics of protests from various aspects of being in America in 2017 (Caruso \& Love, 2017).

Whereas in Indonesia in 2017, according to data from BPS (Central Statistics Agency), the level of democracy shows data of $72.11 \%$, a high rate of democracy. Freedom of opinion on that year's data also showed an increase; freedom of thought gained a percentage of $78.75 \%$, while information on violent demonstrations or strikes showed a percentage of $29.22 \%$.

One of the causes of the spread of one topic or issue, because many Indonesians are familiar with the internet or internet literacy. By data in 2017 presented by the association in Indonesia APJII (Indonesian Internet Service Providers Association). Indonesian internet users already have as much as $54.68 \%$ of the population. Around 143.26 million of the people of approximately 262 million Indonesians already use the internet, half of Indonesia's population already knows the internet. Every year Indonesian users experience a continuous increase. While social media users in Indonesia, according to the web, we are social in 2018, around 130 million people use social media.

In 2016 Andrew expressed that his work tended to criticize Yogyakarta's high development phenomena, where the related impacts of the "Jogja Ora Didol" issue.
However, many other issues existed that year, such as Papuan independence, the Munir case, the Udin case, the issue of Budiono's existence as vice president, tolerance, and fascism. So that this year the criticism of Antitank tends to criticize the governance of the Mayor of Yogyakarta.

In 2017 and 2018, the expressions of social criticism from antitank tended to contain the issue of the New Yogyakarta International Airpot (NYIA). That is the new airport discourse in Yogyakarta located in Kulon Progo, as reported by Detik.com, a demonstration of the rejection of the construction of the NYIA, which took place in front of the Yogyakarta DPRD building. Demonstrators voiced that NYIA's development had displaced peasants' land, oversized farmers, and condemned the apparatus of violence against farmers Kulon Progo (Raharjo, 2018). Another problem arises, namely the agricultural obstacle where many farmers' land has been evicted. In that year, there were also other issues such as corrupt mass organizations, mining in Papua, the problem of corruption, tax amnesty, and the subject of authoritarianism.

One of the artists working on this topic is Andrew Lumban Gaol or Anti-tank. The uniqueness of Anti-tank's work that makes it different from others in expressing and responding to an issue from antitank is using posters. Andrew is street art that 
moves on poster art or uses paper and then pastes Andrew on wall media, which he considers capable of attracting people's attention. Andrew believes that he made his message capable of being directly involved, physically, or mindfully among people affected by social problems. In his work chasing the public or anyone he thinks can understand and consider his work as part of them, Andrew, where the aesthetic function of Anti-tank's work appears (Jenie, 2016). Andrew responds to social phenomena appointed as results usually see what can be offered from his work. He considered the poster unable to solve the problem. Still, he offered a particular perspective, which was Andrew's perspective so that he was not trapped in the area of "typical" personal communication (Wibisono \& Triantoro, 2016).

Based on the explanation above, the study can see the characteristics and classify the types of criticism, and then map the kinds of criticism that are dominant in the work of the Antitankproject account.

\section{METHOD}

This type of research used in this study is quantitative. The method used is content analysis; content analysis is intended to systematically identify the contents of communication and carried out objectively, validly, reliably, and can be replicated (Eriyanto, 2011). This study's main objective is to post social criticism works in the form of images on the Antitank project. This study's population is a picture of the work on the Instagram account Antitank project from January 2016 to December 2018. Posts with the population in this study, there are 192 images or photos. Forty-six samples were taken because of the many works' many repetitions - data collection techniques using documentation by screenshots and using coding sheets. The validity used in this study was to use content validity. The reliability test used is based on the formula by R. Holsti. 


\section{DISCUSSION}

Table 1. Unit of Analysis for Types of Social Criticism

\begin{tabular}{|l|l|l|l|}
\hline No & Sub Categories & Frekuensi & $\%$ \\
\hline 1 & Social criticism of political problems & 15 & $33 \%$ \\
\hline 2 & Social criticism of economic problems & 3 & $7 \%$ \\
\hline 3 & Social criticism of religious matters & 1 & $2 \%$ \\
\hline 4 & Social criticism of environmental problems & 14 & $30 \%$ \\
\hline 5 & Social criticism of humanitarian problems & 13 & $28 \%$ \\
\hline & Amount & 46 & $100 \%$ \\
\hline
\end{tabular}

Source: Primary Data, 2019

The data entered for the analysis unit of the types of criticism that have the most frequency are social criticism of political problems, which is 15 points, with $33 \%$. Even though only a little adrift of social criticism of environmental issues is the number of points, 14 with a $30 \%$ percentage and criticism of humanitarian problems are projections 13 with a portion of $28 \%$. Simultaneously, the number of social criticism points of economic issues is three, with $7 \%$. The minimum number of points is on social criticism on religious matters, with only one particular with $2 \%$.

Whereby Anti-tank in this work, it is considered that the performance and function of the Indonesian vice president

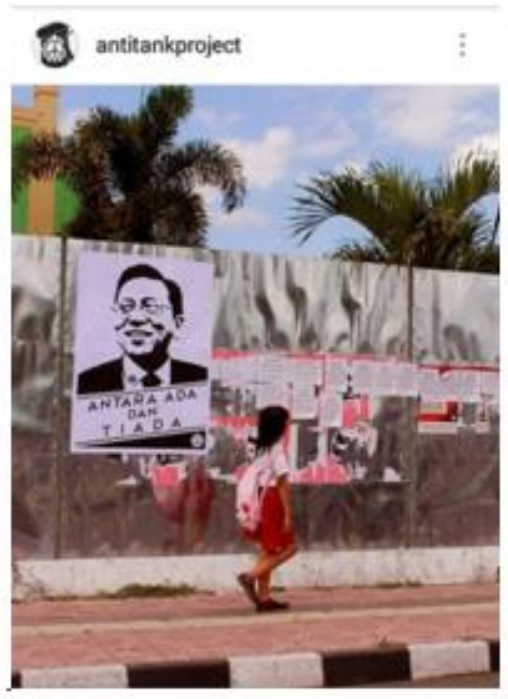

Figure 1. Categories of Social Criticism Political Problems Source: Primary Data, 2019

Boediono as Indonesia's vice president.

for the 2009-2014 period are considered invisible or not optimal, then Anti-tank adds the words "between there and nothing." By what was written on one of Tempo's news websites. The percentage level of satisfaction on the performance of vice president Boediono is $70.4 \%$ 
dissatisfied with its performance, and $19.1 \%$ are satisfied with the vice president's performance in the 2009-2014 period. But on the other side of the web, it is explained that the function of the vice president's performance is indeed not very visible because the performance of the vice president is indeed behind the scenes as someone who helps the president. Boediono's work includes coordinators, policymakers, and thinkers so that the vice president's performance is not very visible (Rizki, 2013). Therefore Anti-tank responded to the issue and produced Boediono's work "between there and nothing."

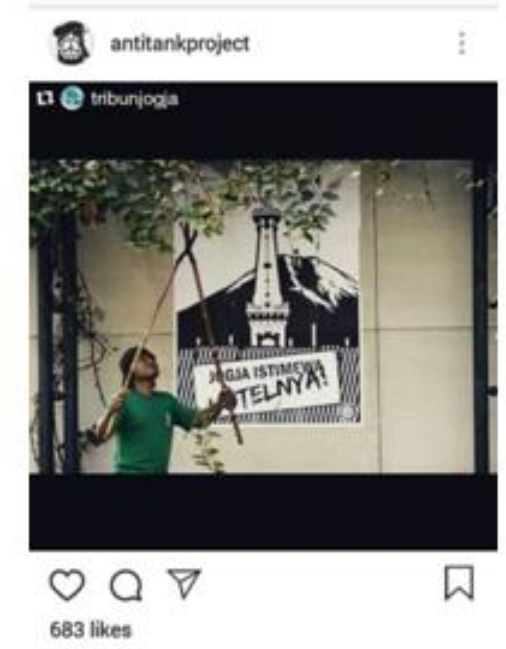

Figure 2. Categories Social Criticism of Environmental Problems Source: Primary Data, 2019

One description of social criticism of environmental problems.

The picture above (Figure 2)

illustrates the environmental problems that occur in Yogyakarta's city with the issue of overgrowing hotel development. Case in one of the hotels in the Miliran area. Residents protested because it caused the residents' wells to dry there. Residents assume that after the construction of the hotel, the well will become difficult to water. But on the contrary, as written on the Kompas website. Whereas it was explained that the cause of drought could be due to drought problems, because the well from Fave Hotel was a well as deep as 80 meters, while the residents' wells were usually as deep as 40 meters, then the Fave Hotel should not disturb their wells and cause drought in the well. Also, the Fave Hotel well has received a permit from a state institution, namely the Environment Agency (Firdaus, 2014).

Another environmental issue raised as an object of criticism by Anti-tank is the construction of NYIA. Where the matter is, the focus is on eviction problems. As written on the Indonesian $\mathrm{CNN}$ news website, the community considers that the eviction is illegitimate and legally owns the land. The displacement was unfavorable to the residents, and they also blocked the excavator from leaving. But according to the Regent of Kulon Progo, Hasto Wardoyo considered that the eviction was by procedures; the government had also prepared land to move or rent houses for them (Akbar \& Muzayyin, 2018).

The work of Anti-tank illustrates the criticism of the issue of the case of a journalist named Munir (Figure 3). The case became the work of Anti-tank because 
one of the reasons was the assumption that Munir's killer had not been found or did not know who had killed the senior journalist. The issue is still raised because this case is considered unfinished. In the Antitank work, an article said, "Calm down! Munir's murderer is still on the loose". This murder case was designated as the work of Antitank because this issue was considered unfinished, or the real culprit of Munir's murder had not been caught or whose identity was unknown. Over the past 14 years, Munir's family has also submitted letters to the government several times to resolve the case, but there has been no response. Because of it, the antitank criticism made this issue in his critique.

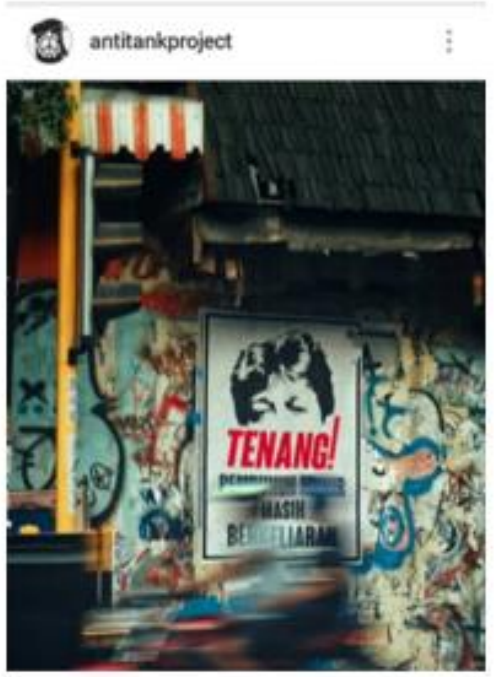

Figure 3. Categories Social Criticism of Humanitarian Problems Source: Primary Data, 2019

The work of social criticism of economic problems can be seen in the picture. The tax here does sound close to the people because people are obliged to pay taxes to the state. But in work made by Antit-tank, he criticized the issue of tax amnesty, which he considered to be an injustice to tax subjects who had low income, and favored tax subjects who had a high income. There is a rejection of tax amnesty. Workers feel that tax amnesty only benefits employers, not workers, feels that if there are people who do not pay taxes for decades, they will be forgiven (Dony, 2016). Whereas on the one hand, what happens to this tax amnesty policy is something positive by the state. Minister of Finance Sri Mulyani Indrawati claims that a ransom of tax amnesty participants in Indonesia is the highest compared to other countries that have implemented a similar policy (Primadhyta, 2016).
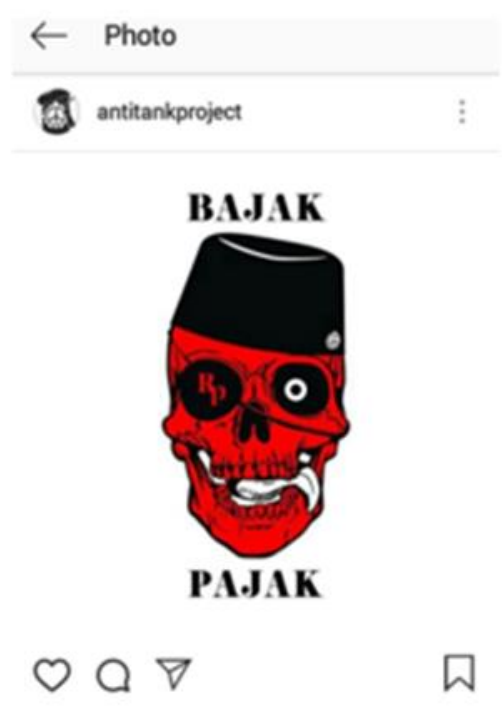

Figure 4. Categories Social Criticism of Economic Problems Source: Primary Data, 2019 
The category of social criticism on religious matters is indeed interesting to discuss. But the religious label itself is a compassionate matter. Spiritual issues can trigger a massive impact or mass because they become the most basic and ideological thing in every individual. Religion becomes a belief and then becomes self-faith. Then, the issues surrounding religion can move a large mass because faith is very attached to every individual, which will voluntarily move each individual's souls if injured. One of the Anti-tank works of social criticism is the problem of religion.

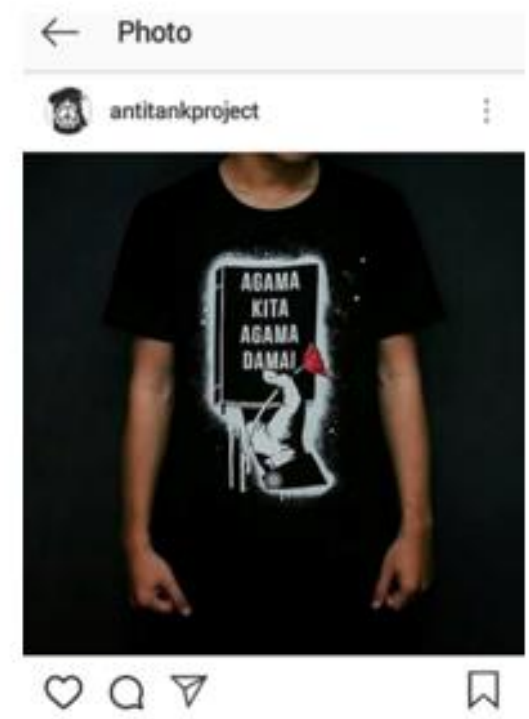

Figure 5. Categories Social Criticism of Religious Matters Source: Primary Data, 2019
Table 2. Critical Object Analysis Unit

\begin{tabular}{|l|l|l|l|}
\hline No. & Sub Categories & Frekuensi & $\mathbf{\%}$ \\
\hline 1 & State Government & 31 & $67 \%$ \\
\hline 2 & Regional government & 5 & $11 \%$ \\
\hline 3 & $\begin{array}{l}\text { Political Parties or } \\
\text { Community } \\
\text { Organizations }\end{array}$ & 3 & $7 \%$ \\
\hline 4 & Society & 6 & $13 \%$ \\
\hline 5 & Educational Institution & 1 & $2 \%$ \\
\hline & Amount & 46 & $100 \%$ \\
\hline
\end{tabular}

Source: Primary Data, 2019

The data entered for the unit of analysis of criticism objects are dominated, from the state government, with a frequency of 31 and $67 \%$. The second place is in the community category, with a sixyear frequency with 13\%. The next sequence is the local government category with a five-frequency frequency, with a portion of $11 \%$. At the same time, political parties or social organizations get three frequencies with $7 \%$. The last sequence is obtained in educational institutions with a frequency of one with a percentage of $2 \%$. 


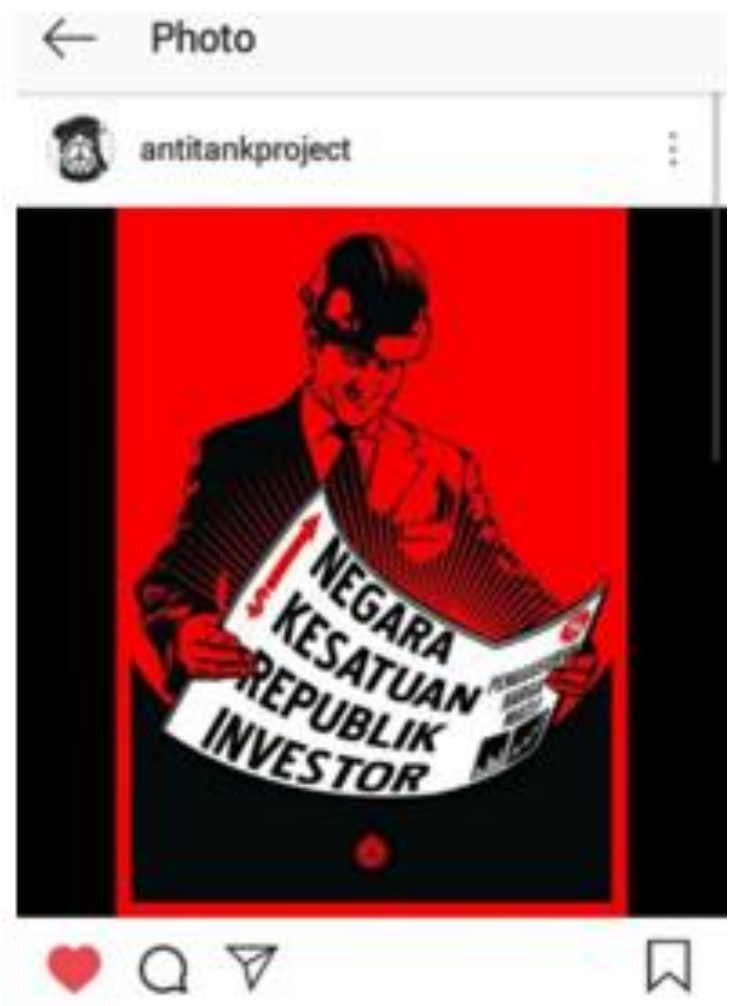

\section{Figure 6. Categories State Government Source: Primary Data, 2019}

The object category of state government criticism is the most because it is broadest in one country. Members of the government, ideology, policies, and issues or problems in the state government are indeed highlights of its citizens. With this issue, the impact of the case will also affect the country directly. So Anti-tank's work gives criticism to the state government so that aspects of the state government go out of their way, which can be controlled using complaints that have the State government's object. Antitank works that read "unitary state republic of investors" compared to NKRI (Unitary State of the Republic of Indonesia). The words written in Anti- tank's work try to criticize the state government because there are issues about the number of foreign and local investors who enter, which gives the impact that there is an eviction or environmental damage to the community.

As happened on Jakarta bay reclamation, each PT's construction permits have been held by each PT. Still, during Anies Baswedan's tenure, 13 islands' permits were revoked, and four islands were not revoked because their permits had already been built that the Jakarta bay reclamation development will adversely affect fishers and the environment (Sari, 2018).

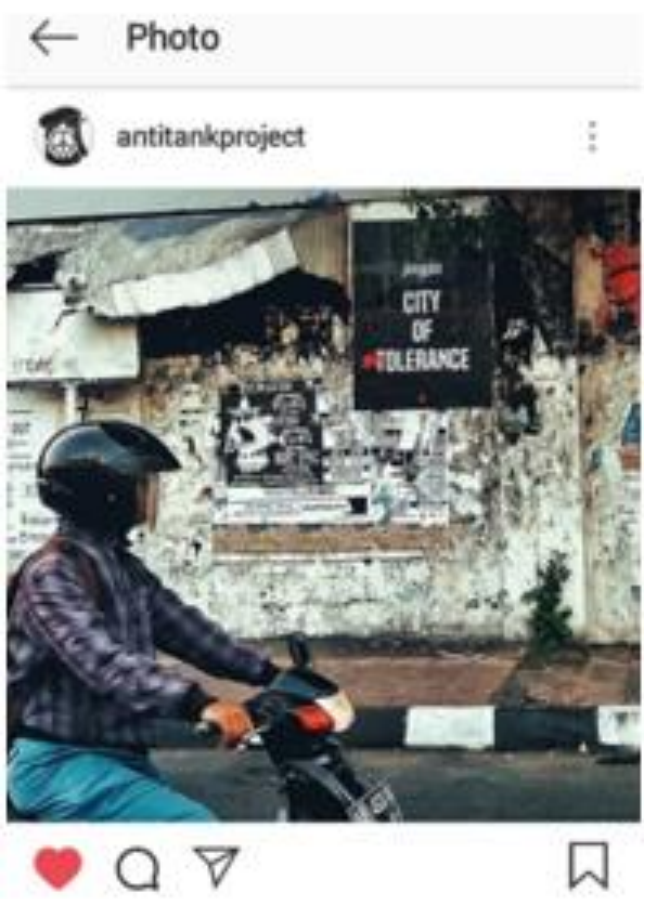

Figure 7. Categories Society Source: Primary Data, 2019 
In the existing Anti-tank works, it has become one of the criticisms that aim to criticize Jogja's citizens who are considered Anti-tank intolerant of intolerance in various fields, be it culture, race, or religion. The citizens of Yogyakarta are aware and know that there are issues or problems in their area that do not uphold tolerance. For this work to stick to and become the beginning of the Yogyakarta, people respect each other even though they have different backgrounds. The subject of public criticism raised on one of the works is a matter of intolerance or intolerance. One of Tempo's online news media. That there are cuts of Catholic headstones in the Kotagede area of Yogyakarta. The gravestone of the Catholic religion was cut into the upper part of the letter "T." Residents in the area demanded that the tombs be sidelined and not put religious symbols on the grave because the tomb would be turned into a Muslim burial, which was initially a public tomb. But the cutting of the gravestone has been approved by the village and family (Wicaksono, 2018).

The object of criticism from Antitank's work criticizes the DIY government (Yogyakarta Special Region) and the Kulon Progo regional government. The result shows Yogyakarta's complaint by the existence of a monument and the inscription "Jogja Special Eviction." As has happened in the land used as NYIA, the airport must displace or free up some land and residential areas in the Temon Kulon Progo area. Procedures and ways of eviction that are considered to use violence are the focus of the issue of the NYIA airport.

The object of criticism from Antitank's work criticizes the DIY government (Yogyakarta Special Region) and the Kulon Progo regional government. The work shows Yogyakarta's complaint by the existence of a monument and the inscription "Jogja Special Eviction," as has happened in the land used as NYIA. The airport must displace or free up some land and residential areas in the Temon Kulon Progo area. Procedures and ways of eviction that are considered to use violence are the focus of the issue of NYIA airport. With its own rules or authority in the form of local autonomy, the regional government will be a worthy object of criticism. Eligibility is because, like the figures in regional governance, it has a significant influence and fame in an area. The rules and policies issued by the region will become public awareness. The rules and procedures that hurt one community will arise from protest or criticism that will reference other parties to participate in the issue. 


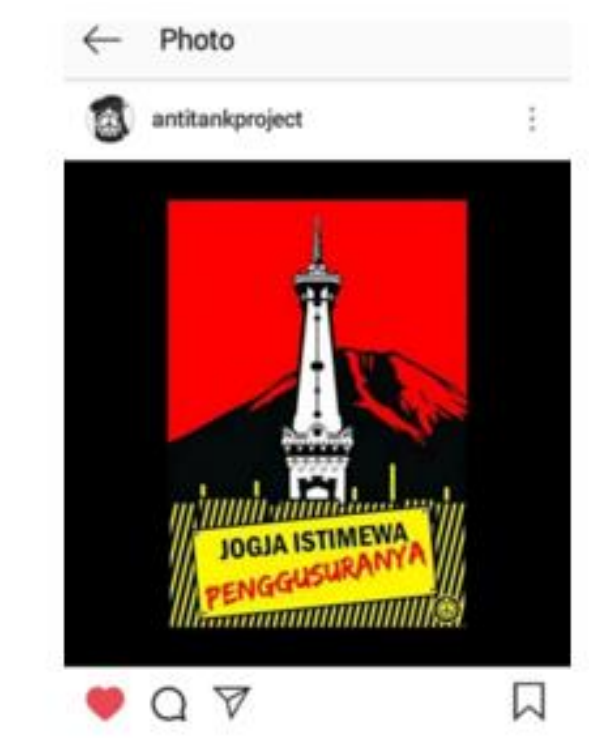

Figure 8. Categories Regional Govermment Source: Primary Data, 2019

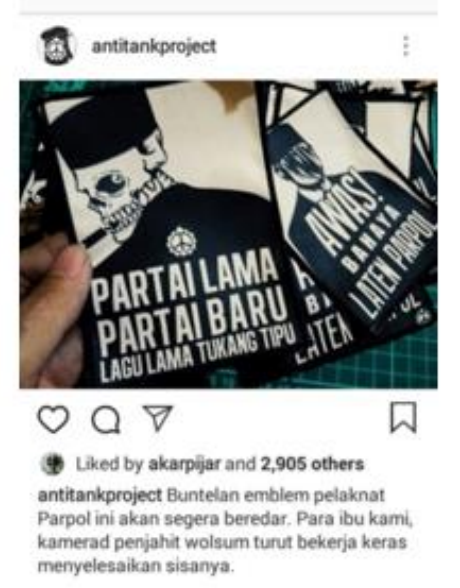

Figure 9. Categories Political Parties or Community Organization Source: Primary Data, 2019

The object of political parties or social organizations is the object of Antitank's work to be interesting to discuss because political parties are one of the elements with a low percentage of satisfaction in performance in the community. In the 2017 polling survey results, political parties ranked lowest or got the smallest percentage with $34 \%$. The people feel unsatisfied or dissatisfied with political parties' performance because they are considered just like that. Promises to pass through because political parties are the beginning and the way for people to enter into a government.

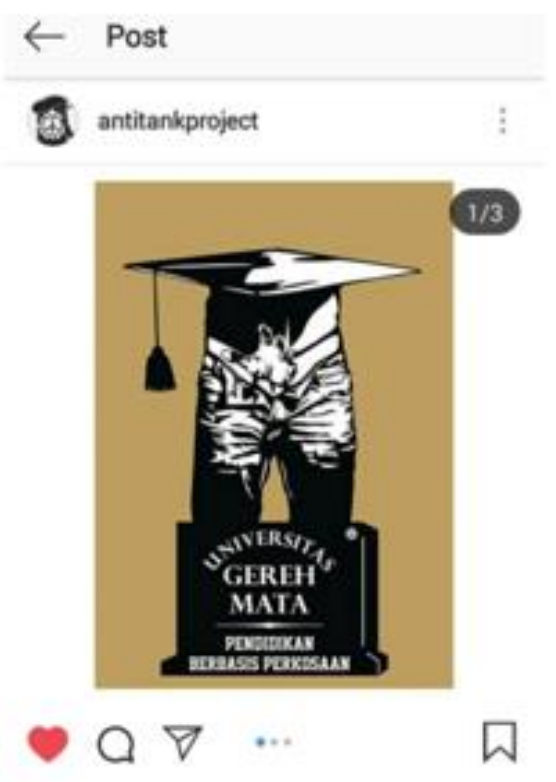

Figure 10. Categories Educational Institution Source: Primary Data, 2019

Anti-tank criticism works, departing from student harassment by students at one of the leading universities in Yogyakarta. This issue is controversial and ongoing because it is considered the slow handling of universities' and universities' injustice to harassment victims. In the media, the agency that accompanied Agni believed that UGM seemed quiet and not transparent in the case because it had not been clear for more than a year. But according to UGM Public Relations, UGM continues to move and continue to proceed and not drag on to deal with cases of sexual abuse against the Agni (BBC, 2018). 
Table 3. Critical Communication Analysis Unit

\begin{tabular}{|c|c|c|c|}
\hline No. & Sub Categories & Frekuensi & $\mathbf{\%}$ \\
\hline 1 & Direct & 11 & $24 \%$ \\
\hline 2 & $\begin{array}{c}\text { Indirect or } \\
\text { Symbols }\end{array}$ & 35 & $76 \%$ \\
\hline & Amount & 46 & $100 \%$ \\
\hline
\end{tabular}

Source: Primary Data, 2019

Within this unit of analysis, the dominant ones are indirect categories or symbols. The number of frequencies obtained in that category is 35 , with a percentage of $76 \%$. Because there are only two categories in this analysis unit, the next type in this analysis unit is the direct category. The category gets 11 frequencies with a $24 \%$ percentage.

One example of communication is the work of direct criticism. As a result, it explains Udin's murder case of a journalist who was considered killed because of sensitive news. In this work, he directly portrays the object of his criticism by putting up a picture of Udin's face and adding it with the words "Udin's journalist was killed because of the news." With this work, Anti-tank also wants to criticize the handling and fairness of the case. News based killings are considered detrimental to those who have more power in the country; hence some interests must be protected.

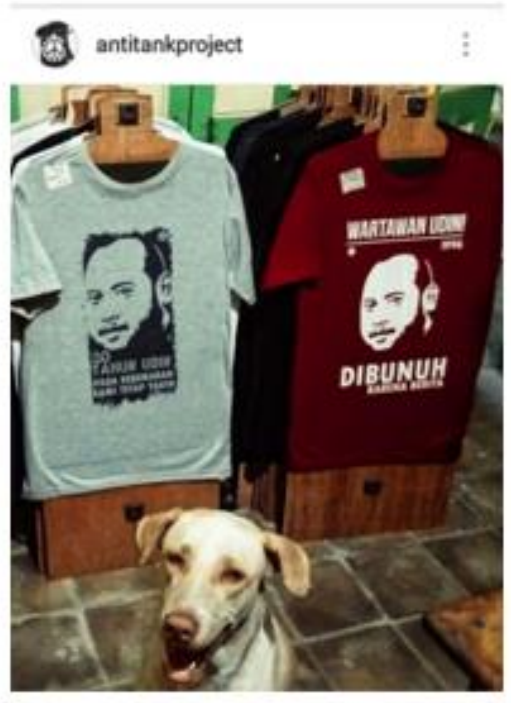

Figure 11. Categories Communication Direct Criticism Source: Primary Data, 2019

One form of a picture of the Republic of Indonesia DPR/ MPR building is depicted in the form of a rat's head, where the rat itself is a symbol of corruption. By the results of the survey described on one of the KPK websites. The survey explained that DPR and DPRD Members got the most corrupt results with the total number of corruptors added from 2004-2018, 247 people. In that year, the highest number of corrupt DPR and DPRD members is in 2018, the number of which is 103 people increased significantly from 2017, which amounted to 20 people (ACCH, 2018). 


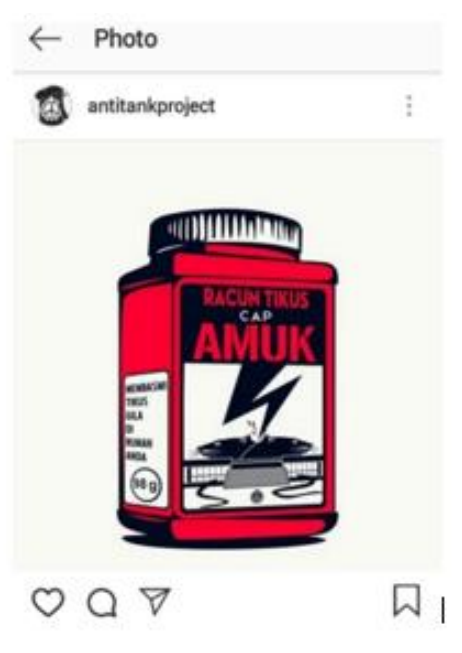

Figure 12. Categories Communication Indirect Criticism or Symbol Source: Primary Data, 2019

In previous studies, social criticism has a function to supervise the existing social system. Social criticism is a tool for integration, not a tool used as integration in a country. Social criticism is also in the way of delivering or carrying out communication that can use various ways. It can be in traditional methods such as sunbathing, expressions, or innuendo, through interpersonal communication, through various social shows and arts in public communication, literary skills, and through the mass media. Social criticism in the delivery can also use a direct way to be easily digested by the community; the second can be by indirect means or symbols that are satirical because it must reveal the meaning in these symbols.

The category of social criticism on political issues gets the highest number of points or dominates. There are influential parts within the political element, such as figures in government positions and their ranks, political figures, government buildings, symbols, state symbols, ideologies that intersect and impact politics. It feels attracted to the attention of the community because indirectly exposed to the community. Exposure can be through news or shows on television, appearing in print media, and through new media. The reason is that government figures are indeed interesting to be used as themes or fulfill high publicity and prominence in journalism. The political field is also related to power in government. The capacity is capable of providing a decision and policyexisting policy, the impact of which will be felt by the community at large. Therefore Anti-tank considers that the political field is an essential issue because it means in the political area that runs many things that are considered off track from the system.

In the category of social criticism of political issues, the critical work of Antitank conveys the contents of the message directly in the form of writing or drawing, which is clearly directed towards the object of criticism. An example of Anti-tank's work depicts the vice president of the 2009 - 2014 period, Boediono. In this work, Antitank provides additional writing in his work that says "between there and nothing." Like the work of the Anti-tank that raised the issue of corruption in the government. The work depicts an Indonesian Parliament/ 
MPR building whose roof is replaced by a mouse head. It can be taken the meaning that it is a form of the depiction of corruption in rats on people who work in government, then represented by the DPR/ MPR RI building. Most of Anti-tank's works do use indirect criticism or symbolic communication.

In this work, he does not want to directly portray the object of criticism, offend now the object of criticism, which can have a sustained impact on Anti-tank if the object of complaint does not feel welcome, not have sufficient evidence. The way of communication of indirect criticism works or symbols becomes a good and wise way to become social criticism. This method is also interesting because it can provide other images that arouse interest in searching for various symbols' meanings. The symbols are also exciting and because they are depicted with other photos. Antitank works that take the way of Communication direct criticism works. If indeed, it is deemed to have sufficient evidence and concrete facts of the issues that exist so that Antitanks dare criticize the object. Therefore the frequency of communication of direct criticism works is less than communication of indirect criticism works or symbols. The transmission of criticism works on the Antitank Instagram account tends to use indirect criticism works or symbols.
If the relationship between Antitank social criticism is taken and the theories used, such as the spiral silence theory, Habermas's critical theory, and the concept of new media. The relationship of social criticism on the Instagram account project with the spiral theory of silence shows that the spiral of silence is a theory where minority groups want to express their opinions but are hampered by the majority group or the ruler. The minority groups seek support through the mass media or through important figures influential to gather supporters who agree to the opinion. The condition or method used by Anti-tank. Initially, Andrew made social criticism printed using paper to be used as a poster, then posted on walls that we're able to be seen and hit many people. After the emergence of new media, Andrew uploaded the news media's work, one of which was Instagram. The Instagram account named Antitankproject, Andrew indirectly impacts the virtual world community with his work, which is to find support for social criticism so that people in cyberspace feel close to the issues. Antitanks still spread their social criticism to the public, despite pressure from the majority group.

With the construction of the new airport NYIA, Anti-tank produced several works posted on the walls so that the public knows that the work has criticized the 
development issues. Still, that reach can only hit urban areas Yogyakarta surrounding. Not stopping there, Anti-tank also uploaded photos of the work in cyberspace through Instagram to find support widely or nationally.

Habermas considers humans
humanizing themselves through
communication. Only by interaction and communication can people dominate society, form social movements, and gain power. This theory is in harmony with what is done by Anti-tank. The basic concept of Anti-tank making works is to provoke the public on an issue and make people who see the work feel close to the case being criticized by the work. One of Andrew's ways is to free his work to be downloaded so that everyone can print and paste the result in other places and other cities. In one way, it led to a movement to disseminate Antitank works with this creative social content.

The latter explains the relationship of the new media concept to the work of Antitank social criticism. New media theory explains that the new media concept has two approaches. The first approach is an interaction that is communicating or interacting in new, face to face communication but in a new way or with the new media. The two integration approaches, namely the new media, are useful for forming communities or cyberspace societies or can help create groups from each individual. Where is the Antitankproject account where Andrew provides photo or video information about existing issues, developing and being impacted on Instagram, it is also the place to display Antitank works containing social criticism on a topic. Instagram features can do feedback or comment on the photo or video. Sometimes Andrew also interacts with these individuals by replying to comments every account that makes a question or statement. To form a picture of which groups are favorable for the work of social criticism of existing issues and groups that are counter to the work of social criticism of the case.

\section{CONCLUSION}

The tendency for Antitank social criticism is more in the political sphere where there are indeed many figures who have power and political policies and regulations that directly affect the community. The criticism works tend to be focused on the object of criticism of the state government, which has a significant influence on one country. In submitting his work, Anti-tank is more likely to choose studies of criticism that are not directly or symbols, so as not now directed at the object of complaint and to avoid the impression of accusing without facts. 
REFERENCE

ACCH. (2018, Desember 31). АCCH. Retrieved from ACCH: https://acch.kpk.go.id/id/statistik/ti ndak-pidana-korupsi/tpkberdasarkan-profesi-jabatan

Akbar, W., \& Muzayyin, A. H. (2018, Juli 25). CNN Indonesia. Retrieved from $\mathrm{CNN}$ Indonesia: https://www.cnnindonesia.com/nas ional/20180725170948-20316949/warga-kulon-progotantang-buldoser-lawanpenggusuran

BBC. (2018, November 9). BBC News Indonesia. Retrieved from BBC: https://www.bbc.com/indonesia/ind onesia-46138337

Caruso, C., \& Love, C. (2017, November 15). The Brink. Retrieved from The Brink:

https://www.bu.edu/articles/2017/c ounting-american-protests/

Dony, B. (2016, September 29). Detiknews. Retrieved from Detik.com: https://news.detik.com/berita/d3309725/para-buruh-juga-demomenolak-tax-amnesty-apaalasannya

Eriyanto. (2011). Analisis Isi: Pengantar Metodologi untuk Penelitian Ilmu Komunikasi dan Ilmu-Ilmu Sosial Lainnya. Jakarta: Prenadamedia Group.

Firdaus, H. (2014, Agustus 6). Kompas.com. Retrieved from Kompas.com: https://regional.kompas.com/read/2 014/08/06/16225191/Sumur.Kering .Warga.Jogja.Aksi.Mandi.Tanah.di. Depan.Hotel\#: :text=Dodok\%20m enggelar\%20aksi\%20mandi\%20de ngan,kekeringan $\% 2 \mathrm{C} \% 20$ termasuk $\% 20$ saat\%20kemarau\%20panjang.

Jenie, K. (2016, Agustus 3). Whiteboard Journal. Retrieved from Whiteboard Journal: https://www.whiteboardjournal.co m/interview/ideas/seni-dan-kritiksosial-bersama-anti-tank/

Primadhyta, S. (2016, September 30). CNN Indonesia. Retrieved from $\mathrm{CNN}$ Indonesia: https://www.cnnindonesia.com/eko nomi/20160930065019-78162245/sri-mulyani-pencapaiantax-amnesty-ri-tertinggi-di-dunia

Raharjo, E. (2018, Januari 16). Detiknews. Retrieved from Detik.com: https://news.detik.com/berita-jawatengah/d-3817538/aksi-demotolak-pembangunan-bandarakulon-progo-digelar-di-dprd-diy

Rizki, M. (2013, Juni 28). Tempo.co. Retrieved from Tempo.co: https://nasional.tempo.co/read/491 831/penyebab-popularitas-wapresboediono-rendah/full\&view=ok

Sari, N. (2018, September 27). Kompas.com. Retrieved from Kompas.com: https://megapolitan.kompas.com/re ad/2018/09/27/07522331/7-faktaseputar-penghentian-proyekreklamasi-di-teluk-jakarta?page=all

Wibisono, T., \& Triantoro, S. (2016). Questioning everything!: kreativitas di dunia yang tidak baikbaik saja : kumpulan wawancara terbaik Warning Magazine. Yogyakarta: Warning Books.

Wicaksono, P. (2018, Desember 18). Tempo.co. Retrieved from Tempo.co: 
https://nasional.tempo.co/read/115

6500/heboh-nisan-tanda-salib-

dinotong-di-vogya-begini-kronono-

logisnya 